\title{
ПРОБЛЕМА РОЗВИТКУ КРЕАТИВНОСТІ У ТВОРЧІЙ СПАДЩИНІ ТОНІ БЬЮЗЕНА
}

\author{
Павленко В. В.
}

\section{ВСТУП}

Педагогічні технології, професійні вміння вчителя, його компетентність повинні бути спрямовані не стільки на запам'ятовування учнями дедалі більшого обсягу навчальної інформації (а нині не тільки навчальної, а й усієї інформації, що має значення для особистісного розвитку), скільки на актуалізацію їхнього розвивального потенціалу.

Ми вважаємо, що сучасна педагогіка не вичерпала всі можливості розвивального навчання. Педагогічні системи розвивального навчання добре зарекомендували себе в початковій школі, але не отримали належного розвитку у старшій, де творча діяльність повинна стати провідною у процесі особистісного становлення.

Потрібно враховувати, що сучасні школярі мають сьогодні доступ до численних освітніх ресурсів, у т. ч. інтернет-ресурсів, які значно розширюють інформаційну базу змісту освіти. 3 урахуванням цього вчителю необхідно вміти працювати в реаліях постіндустріального суспільства, за умов насиченого інформаційного освітнього простору. Він повинен навчати школярів працювати з інформацією (порівнювати, оцінювати, узагальнювати, аналізувати, структурувати), сприяти iiï творчому осмисленню, особистісному сприйняттю. У цьому процесі ключову роль відіграє креативність людини, що забезпечує творчий процес отримання нової інформації, іiї переведення в особистісне поле не тільки логічного, а й емоційного засвоєння, осмислення та запам'ятовування, у т. ч. через механізми неусвідомленого сприйняття та інтуїції.

Необхідність розвитку креативної особистості обгрунтовується величезною роллю, яку відіграє у сучасних соціально-економічних процесах здатність людини висувати нові ідеї, створювати нові ефективні форми, бачити перспективні напрями розвитку різних сфер життя.

У вітчизняній педагогіці накопичений великий досвід розвитку творчої особистості (Г. Альтшуллер, І. Лернер, О. Матюшкін, М. Махмутов, М. Скаткін, В. Сухомлинський, А. Хуторський та ін.). Спеціальне питання розвитку креативності не виділялося як окрема проблема. Креативність як загальна здатність до творчості більшою мірою була предметом інтересу психологів, котрі запропонували 
технології та стратегії розвитку креативності, пам'яті та інтелекту, різні програми та методи розвитку креативних здібностей (Е. де Боно, Т. Бьюзен, А. Грецов, С. Мюллер, О. Осборн, Ф. Цвіккі та ін.).

Соціальний аспект проблеми виходить із суперечності між об’єктивною необхідністю у творчих, креативних особистостях як основному ресурсі створення інноваційної економіки й розвитку соціальної сфери та недостатньою розробленістю і практичним упровадженням у шкільну практику розвивального креативного навчання.

\section{1. Методи логіко-графічного структурування інформації, що сприяють розвитку креативності}

Розвиток креативності пов'язаний із розвитком особистісних якостей людини. Дослідниками визначений зв'язок особистісних рис, які впливають на рівень прояву креативності у процесі діяльності. Наприклад, Т. Любарт до таких рис відносить наполегливість, толерантність до невизначеності, відкритість новому досвіду, індивідуалізм, схильність до ризику та ін. ${ }^{1}$

Н. Лейтес звертає увагу на такі риси особистості, властиві креативним людям, як незалежність суджень, високий рівень пізнавальної необхідності, потреба у яскравих враженнях, задоволення від розумового напруження ${ }^{2}$.

Іншими дослідниками додаються такі риси, як: відкритість розуму, сприйнятливість нового, незвичайного, розвинуте естетичне почуття, захопленість своїми ідеями, зібраність та енергійність, сензитивність, оригінальність.

Педагогічний аспект розвитку креативності повинен бути визначений тими якостями та властивостями особистості, що активізуються, формуються у процесі розвитку креативних здібностей учня: готовністю приходити на допомогу, оптимізмом, гумором та ін. ${ }^{3}$

Т. Любарт стверджує: «Креативність - це здатність створювати продукт, котрий вирізняється новизною та відповідає контексту, у якому він знаходиться» ${ }^{4}$.

Це визначення узгоджується 3 позицією Т. Амабайла, за якою креативність визначається як створення (production) нових (novel), відповідних (appropriate) рішень для відкритих, нерегламентованих

1 Любарт Т., Муширу К., Торджман С., Зенасни Ф. Психология креативности. Москва : Когито-Центр, 2009. С. 45.

2 Лейтес Н.С. Возрастная одаренность и индивидуальные различия. Москва : Институт практической психологии, Воронеж : МОДЭК, 1997. С. 125-137.

3 Ильин Е.П. Психология творчества, креативности, одаренности. СанктПетербург : Питер, 2009. С. 37.

4 Любарт Т., Муширу К., Торджман С., Зенасни Ф. Психология креативности. Москва : Когито-Центр, 2009. С. 20. 
(open-ended) проблем у будь-яких галузях людської діяльності ${ }^{5}$. Новим продуктом може виступати ідея, розповідь, твір, проєкт, модель та ін.

Результатом креативності є створення нових продуктів і рішень (T. Amabile, T. Lubart, A. Colman). Наприклад, A. Colman (2001) визначає креативність як створення ідей і предметів, що є новими, оригінальними, корисними, привабливими, відповідними ситуації та заслуговують на увагу.

Пізніше Т. Амабайл доповнює, що креативність - це не лише створення нових продуктів та ідей, але і їх застосування, наприклад, у створенні нових підприємств, виробництв, програм та ін.

Класифікацію креативних технік і методів запропонувала у своєму дослідженні Е. Бос, котра виділила три види креативних технік: інтуїтивну, дискурсивну, комбіновану. Авторка пропонує три десятки методів i прийомів розвитку креативності. Е. Бос виділила етапи креативного процесу, а саме: мотивацію, латентне незадоволення, з'ясування проблеми, організацію креативного обговорення, пошук ідей, оиінку ідей, визначення рімення, реалізаціюб ${ }^{6}$ Новими для нас є причинно-наслідкові діаграми (запропоновані Каору Ішикави), метод бісоиіаиій, «шість капелюхів мислення» Едварда де Боно, інтелекткарти Т. Бьюзена.

До інноваційних засобів і методів ми відносимо ті, які не тільки дозволяють структурувати та систематизувати знання i досвід, а й дозволяють виявити характер сформованих зв'язків ментальних (розумових) структур, організувати роботу щодо їх удосконалення й розвитку та на основі яких можна було би прогнозувати успішність проявів креативності у навчальній діяльності.

Йдеться про застосування методів логіко-графічного структурування інформації, побудованих на застосуванні таких дидактичних засобів, як: концептуальні (поняттєві) схеми, інтелект-карти (графічний метод образного асоціювання), понятійно-знакові кластери, опорні схеми на основі заданої структури, дивергентні карти (мають вузлову, мережеву структуру, графічне представлення суб'єктом інформації через асоціативно-логічний механізм іiі відтворення) та ін.

У масовій шкільній практиці відомі різні засоби структурування і візуалізації навчального матеріалу. Широко поширені опорні сигнали (конспекти) В. Шаталова, у яких елементи знань зв'язуються різними асоціаціями, причинно-наслідковими відносинами. Відомий метод кластерів (графічного відображення семантичного поля деякого поняття). Підтвердили свою ефективність опорні схеми на основі

5 Amabile T.M. Entrepreneurial creativity through motivational Synergy. Journal of Cretive Behavior. 1997. № 31 (1). P. 18-26.

${ }^{6}$ Бос Э. Как развивать креативность / пер. с нем. Петросян К.А. Ростов на Дону : Феникс, 2008. С. 117. 
заданої структури. Поширилися логіко-графічні схеми А. Сгідеса (перероблення текстів у схеми на основі графічного й семантичного вираження родового співвідношення понять) і логіко-смислові моделі В. Штейнберга, що розробляються в рамках інструментальної дидактики (дидактичного дизайну).

Доповнити список можна знахідками зарубіжної дидактики, такими як:

- концептуальні карти (concept maps) (A. Canas, J. Novak,

D. Gowin);

- інтелект-карти (mind-maps) (T. Buzan);

- концептуальні діаграми (conceptual diagrams) (K. Ishikawa, R. Kaplan, D. Norton);

- когнітивні карти (cognitive maps) (C. Eden);

- візуальні метафори (visual metaphors) (C. Dent-Read, G. Klein, R. Eggleston) та інші аналогічні методи і засоби.

У зарубіжних публікаціях підкреслюється, що перераховані методи можуть ефективно використовуватися для посилення мотивації, уваги, розуміння і пам'яті учнів у ході навчання, відзначається їхній вплив на прояв креативності.

Інтелект-карта становить радіальну діаграму (схему), яка ієрархічно репрезентує семантичні або інші зв'язки між частинами навчального матеріалу, що йдуть від центрального образу (зображення). Більш розширене тлумачення включає репрезентацію слів, ідей, завдань та інших об'єктів, з'єднаних і розташованих навколо центрального поняття або ідеї.

Інтелект-карти як творчий інструмент використовуються для генерування, візуалізації, структурування i класифікації ідей, розв'язання проблем, для організації інформації та тї запису ${ }^{7}$. Т. Бьюзен відзначає вільне асоціювання під час створення карти, представляючи мозок людини у вигляді «великої асоціативної машини», тому такий вид карт належить до асоціативних ${ }^{8}$.

На відміну від концептуальних і когнітивних карт, інтелект-карти будуються на центральній ідеї (центральному образі), мають радіальну структуру (за Т. Бьюзеном - це результат «радіантного мислення»). Важливою властивістю створення інтелект-карт є не тільки кількісний, але і якісний аспект творчого процесу, який включає доречність, логічну впорядкованість інформації, відчуття завершеності та гармонії.

Т. Бьюзен вважає: «Якщо ви хочете генерувати велику кількість ідей, водночас надаючи їм форму й порядок, такі карти допоможуть

${ }^{7}$ Buzan T. The Mind Map Book. BBC Books : London, 1995.

8 Бьюзен Т., Бьюзен Б. Интеллект-карты. Практическое руководство / пер. С англ. Самсонов Е.А. Минск : Попурри, 2010. С. 312. 
вам зробити це надзвичайно легко, даючи можливість організувати їх як свій власний індивідуальний «мозковий штурм» ${ }^{9}$.

Позиція Т. Бьюзена узгоджується 3 думкою В. Дружиніна, Т. Любарта та інших дослідників, котрі звертають увагу на такий критерій креативності, як осмисленість ідей, їхню відповідність контексту, змісту проблемної ситуації.

Під час створення інтелект-карт Т. Бьюзен рекомендує суворо дотримуватися розроблених ним правил: використання центрального образу, асоціювання, вибудовування ієрархії думок, вироблення власного стилю та ін. ${ }^{10}$.

Він також наводить приклади карт, що не $є$ інтелект-картами, оскільки не задовольняють правила їх складання. Т. Бьюзен назвав їх «павутинними діаграмами» - це деякі мережеві моделі: вузли, зв'язки, розгалуження ${ }^{11}$.

Однак ми звернули увагу на потенціал використання таких діаграм, оскільки вони схематично показують модель дивергентного мислення, тобто мислення «розходиться», «іде» в різних напрямках (divergent розходитися), які не $є$ тільки асоціативним. Його детерміновано причинно-наслідковими зв'язками, що визначають вузли «перемикання» асоціативних потоків, логічними закономірностями розгортання семантичної області будь-якого поняття (системи понять).

Алгоритм складання опорної схеми на основі заданої структури:

1. Визначення теми навчального предмета.

2. Позначення мети (кінцевого результату, якого потрібно досягти: вивести формулу, закон, виконати класифікацію та ін.).

3. Виділення логіки розгортання навчального матеріалу (послідовності дій щодо заповнення схеми).

4. Виділення опорного матеріалу та блоків для самостійної роботи учня.

5. Добір допоміжного навчального матеріалу (формул, позначень, умовних знаків та ін.).

6. Установлення міжпредметних зв'язків і способів їх фіксації у схемі.

7. Добір попередніх завдань (якщо необхідно), розв'язання яких допомагає учням у процесі роботи зі схемою розв'язати складну задачу або виконати необхідне перетворення.

8. Виділення необхідних структурних блоків інформації (висновку за формулою, пояснення закону, практичних завдань, досліджень та ін.).

${ }^{9}$ Бьюзен Т. Супермышление / пер. с англ. Самсонов Е.А. Минск : Попурри, 2006. C. 143.

${ }^{10}$ Бьюзен Т., Бьюзен Б. Интеллект-карты. Практическое руководство / и пер. С англ. Самсонов Е.А. Минск : Попурри, 2010. С. 106.

${ }^{11}$ там само. С. 130. 
9. Продумування колірного оформлення схеми для її ефективного сприйняття.

Розробка опорної схеми $є$ непростим завданням навіть для досвідченого вчителя, оскільки потрібно не тільки викласти знання в певній системі, а й передбачити послідовність його представлення й роботи 3 ним із погляду сприйняття матеріалу учнем і формування логіки розвитку навчальної теми.

Наведений алгоритм дозволяє уникнути подібної помилки та розробити якісний дидактичний продукт (схему).

Допрацьована учнями опорна схема, попри свою структурну заданість, має ознаки креативності, у ній відображається індивідуальний стиль сприйняття й відображення інформації, мислення школяра.

\section{2. Ментальні картки Тоні Бьюзена}

Майнд-карти $€$ одним із ефективних методів навчання, який був запропонований англійським психологом і лектором Т. Бьюзеном. Карти пам'яті були створені для запам'ятовування великої кількості матеріалу, а також для його спрощення, розуміння й економії під час конспектування. Метод був розроблений у 70-х рp. XX ст., проте досі $\epsilon$ популярним. Він передбачає конкретизацію та візуалізацію. Не завжди вдається повністю підтримувати індивідуальний підхід до кожного учня з урахуванням його виду пам'яті чи домінування аналізатора, адже те, що допомагає одному, не завжди допоможе іншому, проте застосування цього методу є універсальним для всіх школярів.

Питання впровадження технології майнд-карт в освітній процес досліджували у своїх працях Б. Санто, В. Хартман, Т. Бьюзен, Й. Шумпетер Б. Твіст.

Перші ідеї розвитку своїх інтелектуальних можливостей виникли у Т. Бьюзена, коли він ще був студентом. Т. Бьюзен зіткнувся із проблемою засвоєння великого об'єму навчального матеріалу й помітив, що мозок не здатен впоратися, коли отримує занадто велике навантаження. Проблема полягала ще й у тому, що зусилля, витрачені під час навчання, не сприяли успішності. Т. Бьюзену, навпаки, здавалося, що чим більше він конспектував і вчив матеріал, тим гіршими були його результати. Т. Бьюзен ділиться своїми спогадами: «На другому курсі університету я якось зайшов до бібліотеки й запитав, чи немає книг про теорію мозку та його практичні можливості. Бібліотекар, не роздумуючи, направила мене у відділ медичної літератури. Коли я пояснив, що не збираюся робити операцій на головному мозку, а хочу тільки лише правильно його використовувати, мені ввічливо відповіли, що таких книг, певно, узагалі немає» ${ }^{12}$.

${ }^{12}$ Бьюзен Т. Супермышление / пер. с англ. Самсонов Е.А. Минск : Попурри, 2006. C. 11. 
Отже, власні пошуки дослідника призвели до появи нових креативних методів. Передусім Т. Бьюзен дійшов висновку, що ключ до справжнього успіху потрібно шукати у відповіді на запитання, наскільки раціонально використовуються мисленнєві можливості та інтелект. Т. Бьюзен намагався знайти відповіді у спеціальній літературі. Окреслені запитання (які є прийоми ефективного запам'ятовування? як знайти шлях до творчого мислення? як удосконалити навчання? як опанувати техніку швидкого читання? яка природа мислення?) привели Т. Бьюзена до грунтовного вивчення психології, нейрофізіології, нейролінгвістики, мнемотехніки та кібернетики.

Зрештою Т. Бьюзен зробив висновок: щоб досягти хорошої роботи мозку, потрібно дати можливість його потенційним здібностям працювати сумісно, а не розглядати їх як окремі самостійні частини. Наприклад, один із прийомів мнемотехніки: конспектуючи, використовувати хоча б ще два кольори для виділення інформації. Таким чином до роботи залучаються одразу дві ділянки головного мозку: за текст конспекту й мову відповідає ліва півкуля, а за різні кольори - сприйняття, що є функцією правої півкулі.

Досягнувши успіхів у навчанні та зрозумівши, як саме потрібно вчитися, Т. Бьюзен почав допомагати іншим. Переважно це були школярі, студенти коледжів, котрі відставали у навчанні. Результати були позитивними, і в майбутньому ті, хто відставав у навчанні, завершували його з відзнаками.

Після успішного закінчення університету Саймона Фразера Т. Бьюзен повернувся до Англії. Деякий час він працював учителем. У 1969-1970 pр. він стає редактором «The International Journal of Mensa» та продовжує досліджувати проблему розвитку мозку. Тоді ж він винайшов методику для швидкісного читання та почав розробляти перші майнд-картки.

До розробок інтелектуальних карт згодом долучився рідний брат Т. Бьюзена Барі. Б. Бьюзену більше сподобався спосіб організації конспектів, на відміну від Тоні, якому подобалося саме конспектування. Брати 3 різних позицій підходили до створення карт, тому їхні розробки дещо відрізнялися, але взаємний обмін досвідом прискорив роботу над загальними концепціями. На початкових етапах розробки Т. Бьюзен вважав, що інтелект-карти можна використовувати передусім як мнемотехнічний засіб. Б. Бьюзен переконав брата, що винахід стосується методології, яка застосовуватиметься для розвитку творчого мислення.

У 1970 р. Т. Бьюзен вирішує написати про свій метод, зароджується ідея створення серії книг «Енциклопедія людського мозку та його можливості». У 1973 р. він співпрацює над створенням серіалу під назвою «Навчіть думати». Після цього проєкту його ідеї були висвітлені у п'ятьох книгах: «Використовуйте свою пам'ять», 
«Удосконалюйте свою пам'ять», «Навчіть мислити», «Підручник швидкого читання», «Картами розуму». Теорія інтелект-карт була презентована світові у 1974 р. після опублікування книги «Працюй своєю головою», на основі якої в 1995 р. вийшла доповнена новими ідеями книга «Супермислення».

У ході своєї викладацької діяльності Тоні Бьюзен вивчив широкий спектр можливостей i переваг, які надає користування інтелекткартами. Він поєднав практичний метод із теорією людського мозку, а також сформулював низку правил для коректного створення карт.

Т. Бьюзен сьогодні, незважаючи на свій поважний вік, продовжує займатися активною діяльністю. Він проводить лекції по всьому світу та $є$ учасником різноманітних конференцій. Т. Бьюзен входить до числа найвідоміших спікерів. Він є членом Міжнародної ради психологів ${ }^{13}$.

Щороку кількість послідовників теорії радіантного мислення та використання створених на його основі карт пам'яті збільшується. Послідовників цього методу можна зустріти майже в кожній країні світу, тому з метою забезпечення взаємної підтримки та спілкування було створено Організацію користувачів ментальних карт.

Карта пам'яті, інтелект-карта, карта асоціацій, ментальна карта, діаграма зв'язків - усі ці назви $є$ синонімічними. Карти асоціацій широко застосовуються, вони створені не лише для структурування інформації, але і для продукування власних думок, тобто планування, прогнозування. Загалом, на думку розробника, створення такої карти це спосіб фіксації процесу мислення, який найбільш подібний до процесу зародження думок у нашому мозку.

Більшість людей, на думку Т. Бьюзена, помилково вважають, що саме ідея одночасного залучення двох півкуль під час роботи лежить в основі інтелект-карти. Звісно, карта розуму протиставляється комп’ютеру. Проблема комп'ютера в тому, що він використовує лише ліву півкулю, а це зменшує потужність мозку. Карта пам'яті сприяє сумісній роботі двох півкуль, що розкриває ввесь потенціал мозку, і це лише підтвердження іiї результативності.

Проте центральним у концепції Т. Бьюзена є вчення про так зване радіантне мислення - природну здатність мозку мислити асоціативно від «центру до периферії». Ми сприймаємо інформацію цілком, ніби скануючи їі, тому швидко втомлюємося від звичайних лінійних текстів.

Поняття «радіантне мислення» (від радіант - точка небесної сфери, 3 якої ніби виходять видимі шляхи тіл з однаковими напрямами швидкостей, наприклад, метеоритів одного потоку) належить до асоціативних способів мислення, відправною точкою яких $\epsilon$ центральний об'єкт. Стандартне конспектування не містить таких

${ }^{13}$ Бьюзен Т. Супермышление / пер. с англ. Самсонов Е.А. Минск : Попурри, 2006. C. 18. 
складників, як колір, асоиіації, просторові орієнтації, графічне подання інформації, але ці елементи є важливими для ефективності навчання. Таким чином, завдяки нестандартним підходам навчання стає цікавішим, і діяльність мозку поліпшується. Лінійне конспектування дає нам оманливе відчуття завершеності, готовності, воно обмежує мисленнєві процеси, не забезпечує стимулювання творчих сил мозку й надалі призводить до зниження здатності запам'ятовування та концентрації уваги. Мозок - це система обробки інформації. Кожен спогад, думка, відчуття, кожне слово, звук, рух тощо може бути презентованим у вигляді центрального сферичного об'єкта, від якого відходять відгалуження. Ці відгалуження - асоціації. Асоціація - це зв'язок між окремими уявленнями, за якого одне з уявлень викликає інше. Наприклад, слово погода викликає в нас асоціації: хмарна, сонячна, дощова, вітряна, спекотна та ін. Кожна така асоціація здатна утворювати майже нескінченні зв'язки з іншими асоціаціями. Кількість асоціацій можна назвати пам'яттю або архівом. Тому мислення загалом можна уявити у вигляді великої асоціативної машини. Мозок нагадує потужний біокомп'ютер, у якому думки, ніби промені, розходяться до нескінченних інформаційних вузлів.

У ході навчання передусім запам'ятовуються:

- знання, отримані на початку та в кінці навчального процесу;

- інформація, яка запам'ятовувалася через асоціації;

- інформація, що миттєво залучає рецептори будь-якого із п'яти органів чуттів;

- будь-яка інформація, у котрій наявна емфаза (підкреслення, виділення чогось різними засобами: інтонацією, повторами, наголосом, порядком слів тощо), яка підкреслює важливість і своєрідність інформації;

- інформація, що цікавить суб'єкта ${ }^{14}$.

Деякі люди пояснюють причину відсутності бажання вивчати якусь інформацію (яку, звісно, вони вважають непотрібною, некорисною) тим, що вони таким чином засмітять свій мозок і не залишать місця для потрібних знань. Проте таке судження $є$ помилковим. База одиниць інформації та асоціацій, які відгалужуються від них у вигляді інформаційних каналів, нараховує декілька квадрильйонів.

Інтелект-карта допомагає зрозуміти різницю між здатністю зберігати обсяг інформації, котра може бути зафіксована в пам'яті, що дозволяє демонструвати метод інтелект-карт, і ефективністю зберігання інформації, на успішність якої розрахований метод.

Ментальна картка - крок уперед на шляху прогресу від лінійного (одновимірного) через латеральне (двовимірне) мислення. Це графічне

${ }^{14}$ Бьюзен Т. Супермышление / пер. с англ. Самсонов Е.А. Минск : Попурри, 2006. C. 29. 
вираження процесу радіантного мислення, цілком властиве роботі головного мозку. Карти асоціацій використовують увесь спектр можливостей: оперування словами, образами, числами; логічність, ритм, колір і просторову орієнтацію. Початківцям у створенні карт знань автор радить спершу ознайомитися із книгою «Супермислення», а також прочитати ще деякі рекомендації у книзі під назвою «Використовуй свій розум».

Спочатку аркуш, на якому буде зображуватися схема, потрібно розташувати горизонтально. Інтелект-карта завжди базується навколо центрального образу. Перший крок під час ії створення - з'ясування базових порядкових ідей (БПІ), що належать до центрального образу. Ці ідеї - сукупні ключові концепції, у рамках яких потрібно вмістити додаткові категорії. Наприклад, поняття «самоосвіта» - це центральний образ, який має такі БПІ: досвід, читання, інтернет-ресурс, спілкування, помилки. Від БПІ відходять ще розгалуження.

Розглянемо одну з базових підпорядкованих ідей, наприклад, поняття спілкування. Воно поділяється на міжособистісне, дистанційне та віртуальне. Звісно, цю інформацію можна доповнювати далі.

Центральний образ повинен бути об'ємним, мати правильне положення (посередині). Це може бути не лише слово, а й малюнок. Головне, щоб для його виділення використовувалося не менше трьох кольорів. Перша базова ідея повинна бути написана великими друкованими літерами над потовщеною лінією, розмір якої відповідає розміру слова. Потовщені лінії з'єднують базові порядкові ідеї 3 центральним образом. Важливо, щоб потовщена лінія кожної нової БПІ мала різний колір без повторів, що допомагає цілісному сприйняттю. Від БПІ відходять асоціації, які характеризують ії. Слова розміщують лише на гілках, не потрібно вписувати їх у фігури. Гілки повинні бути гнучкими, органічними. Розмір літер і товщина лінії повинні змінюватися залежно від важливості ключового слова. Рекомендується використовувати також малюнки до асоціацій, тому що вони підсилюють сприйняття. Таким чином, створюється асоціативна сітка, у якій можна формувати ідеї другого, третього, четвертого рівнів. Той, хто створює карту, може використовувати свої спеціальні коди. Якщо елемент однієї БПІ стосується й іншої базової ідеї, то елемент з'єднують стрілкою з іншою БПІ. Важливо, щоб гілки не змішувалися одна з одною, організація простору має значення. Потрібно, щоб увесь простір був заповненим, але гілки повинні розташовуватися нещільно. Для зручності гілки також нумерують ${ }^{15}$.

15 Інтелект-карта: мистецтво мислити ширше. URL: http://osvitanova.com.ua/posts/1232-intelekt-karta-mystetstvo-myslyty-shyrshe 
На думку Т. Бьюзена, учитель насамперед повинен формувати ментальну грамотність, уміння вчитися. Базові знання повинні бути стійкими, щоб на їхній основі будувалися нові.

Інтелект-карти сьогодні використовуються в педагогічній практиці як допоміжний метод. Вони $є$ ефективним інструментом структуризації й аналізу інформації. Використання цього методу має деякі переваги. Завдяки візуалізації забезпечується успіх у засвоєнні інформації. Наочність карт допомагає побачити ідею та ії компоненти, додаткові позначення відразу допомагають зрозуміти, що означає інформація на карті. Усі ідеї, розміщені таким чином на аркуші, сприяють продукуванню шляхів розв'язання завдань. Учитель може скористатися картами навіть під час складання плану уроку.

Крім певних організаційних робіт i планування, метод безпосередньо застосовується у процесі навчання. Спочатку вчитель має виокремити тематичні розділи (загалом це можуть бути саме ті, що наявні в підручнику). У кожному розділі потрібно окреслити головну тему та мету, які становлять інформаційний блок. Запам'ятовування приносить успіх, коли вчитель разом із розкриттям змісту інформаційного блоку пояснює, чому інформація записана таким чином і що дає певний шифрований запис. Учні повинні зрозуміти, що механічне запам'ятовування опорного конспекту повністю не гарантує фундаментальності та міцності знань, тому що робота 3 підручником також $є$ важливою та необхідною.

Існують види майнд-карт, поділ яких залежить від того, як учитель репрезентує інформацію (потрібно намагатися рухатися від детального до символічного). Це такі види:

Деталізована карта - навчальний матеріал максимально заповнений різними доповненнями тощо.

Схематична карта - подається в узагальненому вигляді головних ідей, $є$ спрощеним варіантом.

Символічна карта - оперує графічним зображенням інформації (символами, малюнками, протилежними поняттями).

Звісно, найкраще застосовувати всі види карт, рухаючись від деталізації до символічності.

Найперше, що має зробити педагог, - сформувати в учнів уміння розпізнавати головне поняття та підпункти, із яких виходять розгорнуті положення. Учні створюють карти колективно (учитель розділяє учнів на групи, кожна 3 яких має своє завдання і в кінці презентує свою роботу) або індивідуально (кожен учень розробляє карту самостійно). На початкових етапах учитель розробляє інтелект-карти разом з учнями, проте надалі має сприяти тому, щоб учні вміли робить їх самостійно. Таким чином, коли учень сам створює карту, він шифрує інформацію своїм способом, який для нього особисто $є$ найкращим і зрозумілим. 
Ментальні картки допомагають у навчанні: учні проявляють активність, пришвидшується процес засвоєння матеріалу, підвищується та полегшується запам'ятовування. На основі інтелект-карт відбувається «мозковий штурм», що передбачає активне обговорення та висвітлення ідей, а також огляд презентацій.

Зазначений метод $є$ альтернативою проведенню різноманітних видів і форм контролю: письмової, самостійної роботи, усного опитування, групового взаємоконтролю, особистісного контролю, перевірки домашнього завдання тощо. Оцінки, отримані школярем, записуються на аркуші як результат здобутих знань і кодуються. Розробляючи 3 учнями ментальну карту, учитель має змогу перевірити, як учні орієнтуються в темі, який у них рівень сформованості вмінь і навичок ${ }^{16}$.

Отже, різноманіття сфер застосування ментальних карт змінює уявлення про складники навчального процесу. Проте насамперед це зручний спосіб занотовування інформації, завдяки якому виділяється головне та відділяється зайве. Форми та лінії формують ієрархічну структуру, під час аналізу текстів виникає розуміння зв'язків між поняттями. Карти асоціацій розвивають критичне мислення та задають вектор для одержання позитивних результатів. Учні концентрують увагу на важливих речах, необмеженість дає вільний простір для висловлення, і тому виникає позитивне ставлення до навчання ${ }^{17}$.

\section{3. Використання інтелект-карт на уроках іноземної мови}

Особливість уроку іноземної мови полягає у тому, що до нього висувається низка своєрідних вимог, які відрізняють його від інших занять. Урок іноземної мови має на меті сформувати в учнів мовну компетентність, до якої входять: засвоєння граматики, лексики, фонетики, стилістики, орфоепічні та правописні вміння. Ці лінгвістичні основи забезпечують формування комунікативної компетентності, здатності учнів використовувати свої навички в мовленні. Метою вивчення іноземної мови $\epsilon$ досягнення школярами такого рівня комунікативної компетентності, який був би достатнім для здійснення спілкування в усній (говоріння, аудіювання) і в писемній (читання, письмо) формах у межах вивчених комунікативних сфер, тематики ситуативного мовлення та на основі вивченого мовного й мовленнєвого матеріалу. Для досягнення мовленнєвої компетентності потрібно чітко сформулювати практичні цілі ${ }^{18}$, зокрема формування в учнів умінь і навичок здійснювати спілкування в усній і письмовій формах у межах

16 Інтелект-карти - реальний крок у сучасній освіті. URL: http://shkola.ostriv.in.ua/publication/code-64C00512193D9
17
Mindmap
effektive
Lernen
Methode.
URL: https://www.edrawsoft.com/de/mindmap-examples-for-students.php

18 Іноземна мова. Програми для загальноосвітніх навчальних закладів, 59 класи. URL: https://www.ippo.if.ua/predmety/inoz/index.php?r=site/stattya\&id=191 
сфер і тематики, визначених навчальною програмою для кожного профілю, дотримуючись традицій і норм, прийнятих у країні, мова якої вивчається.

Таким чином, із метою перевірки ефективності методу інтелектуальних карт, а також із метою впровадження інноваційних технологій було застосовано зазначений метод на уроках іноземної мови $з$ учнями 5 класу (30 осіб).

Школярі спочатку детальніше ознайомилися 3 інтелект-картами. Їм була надана інформація про метод і його успішне застосування. Пояснення, як створити карту, про способи іiї розроблення, заповнення, розміщення понять було зроблено на прикладі вивченої теми «Tagesablauf». Метою вивчення цього матеріалу було формування лексики за темою «Розпорядок дня», що стосується вивчення часу (за годинником) і занять, хобі в різний час. На дошці було записано слово «Ноbby», учням було поставлено завдання дописати німецькою мовою слова та вирази, що стосуються теми.

Учні змогли створити речення 3 іншими словами. Таким чином відбулося повторення й залучення їх до майбутньої роботи та розробки плану дослідження.

Одним із завдань дослідження було розроблення власних інтелекткарт і впровадження їх на уроках. Використання карт відбувалося в кількох напрямах, таких як: контроль (опитування), лексичний аспект, вивчення граматичного розділу теми, повторення. Звісно, учні записували матеріал і у звичайному, лінійному вигляді.

На момент дослідження учні розпочали вивчати нову тему «Einkaufen und Kochen». Тема «Покупки та приготування їжі» охоплює велику кількість слів, пов'язаних із назвами овочів, фруктів, харчових продуктів, тому тема складається 3 деяких підтем, які визначають покрокове вивчення теми й основні компетенції з головної теми: «Lebensmittel und Getränke» (учні називають продукти та напої) «Mengenangabe» (називають кількість, вагу та назви упаковок продуктів) «Dialoge beim Einkaufen» (складають діалоги під час покупок, називаючи ціни).

Одна із вправ у підручнику на впорядкування використовувалася для того, щоб учні зрозуміли логіку побудови карти асоціацій. У цій вправі вже були визначені слова-підпункти, до яких за умовою потрібно було віднести подані слова. Хід виконання був таким: спочатку школярі прочитали перелік слів і відповідні їм слова-поняття, зробили переклад. У робочих зошитах написали тему «Essen» (їжа) і від неї намалювали гілки (слова з таблиці): Obst (фрукти), Gemüse (овочі), Suppen (перші страви), Salate (салати), Getränke (напої), Süßigkeiten (солодощі). Від цих слів малювали ще розгалуження та записували слова, які підходили за змістом. Отже, Obst (фрукти): Orangen (помаранчі), Aprikosen (абрикоси), Äpfel (яблука), Birnen (груші), 
Pflaumen (сливи) та ін. Загалом учні впоралися із завданням і зобразили карту. Проте малювання карт, за правилом їх створення, передбачає використання різних за товщиною кольорових ліній, використання певних позначень, тому за браком часу та необхідного обладнання карти були досить схематичними. Через це домашнім завданням для учнів було намалювати карту за таким самим принципом на основі слів, що стосуються їжі, але зробити ії повне оформлення. Кожен учень мав свій підхід, що є позитивним.

На наступних уроках ми розглянули спосіб використання карт у граматичному аспекті: вивчення відмінювання модального дієслова.

У кінці дослідження було проведено тест-опитувальник і зроблено висновок. Учні відповідали на запитання «так» або «ні». Результати опитування засвідчили, що учням сподобався метод, їхнє ставлення до процесу створення карт загалом було позитивним, вони отримали хороші оцінки, для них це був новий досвід. Можна вважати, що метод $\epsilon$ корисним і повинен застосуватися на уроках.

Отже, інтелект-карта використовується під час планування й організації уроку, а також під час навчання. Учитель має виокремити тематичні розділи й у кожному з них окреслити головну тему та мету, які становлять інформаційний блок. Важливо, щоб учні розпізнавали головні поняття та підпункти. На уроках карти створюють колективно, у групах або ж самостійно. Існують такі види карт: деталізована, схематична, символічна. Можливе застосування всіх видів карт. Найкраще рухатися від деталізації до символічності. Метод є корисним і цікавим для школярів, його ефективність було підтверджено у процесі навчання учнів 5 класу.

Метою вивчення іноземної мови у школі $є$ формування в учнів комунікативної компетентності, яка передбачає вміння спілкуватися в усній (говоріння, аудіювання) та в писемній (читання, письмо) формах у межах вивчених комунікативних сфер. Під час дослідження було встановлено, що інтелект-карти є хорошим засобом для вивчення лексики, нового граматичного матеріалу, а також для перевірки рівня знань і повторення. Ментальні карти мотивують, полегшують процеси запам’ятовування та сприяють активності учнів на уроці.

\section{ВИСНОВКИ}

Креативне навчання - це тип навчання, для якого провідною $€$ творча діяльність учнів, що здійснюється в навчально-пізнавальному процесі. Воно характеризується такими особистісними утвореннями, як суб'єкт творчої діяльності та креативного потенціалу, сприяє соціалізації учнів і досягненню ними значущих цілей як особистісного, так і соціального змісту.

Ми провели дослідження ефективності впровадження методу інтелектуальних карт Т. Бьюзена на уроках іноземної мови. Метою 
дослідження було вивчення можливостей застосування відомого й популярного методу у школі. У процесі виконання поставлених завдань мету було досягнуто.

Насамперед ми розглянули фізіологічні основи розвитку учнів, а саме як працює мозок. Було з'ясовано, що метод інтелект-карт об'єднує різні можливості обох півкуль, а це позитивно відображається на вмінні застосовувати різний підхід до виконання завдань. Також було розглянуто види пам'яті: словесно-логічну, образну, рухову, довільну й мимовільну, механічну й логічну, безпосередню (автоматичну) й оперативну. Було вивчено види пам'яті за поділом тривалості збереження матеріалу (миттєву, короткочасну, оперативну, тривалу, генетичну пам'ять) і за аналізатором, який переважає (рухову, зорову, слухову, сенсорну, емоційну). Від виду пам'яті залежить, як найкраще організувати навчання для школяра. Було встановлено, що інтелектуальні карти допомагають розвитку критичного мислення, а це $\epsilon$ важливою передумовою розвитку підлітків. Перевагою методу є його універсальність для всіх школярів незалежно від індивідуальних особливостей пам'яті.

Перш ніж перевірити метод на уроках, ми ознайомилися 3 основними правилами створення карт. Потім ми проаналізували навчальний матеріал для уроків іноземної мови у 5 класі. Розробивши спочатку деякі карти, ми запропонували та репрезентували учням такий спосіб роботи. Упровадження здійснювалося з метою засвоєння учнями нового лексичного та граматичного матеріалу і його перевірки, а також для повторення раніше вивченого матеріалу. Більшість учнів впоралися із завданням, їм більше сподобалося створення карт, ніж звичайне, лінійне записування лексем у словники. Дослідження завершилося позитивним результатом співпраці з учнями.

\section{АНОТАЦІЯ}

У статті встановлено, що майнд-карти $є$ одним із ефективних методів навчання, який був запропонований англійським психологом і лектором Т. Бьюзеном. Карти пам'яті були створені для запам'ятовування великої кількості матеріалу, а також для його спрощення, розуміння та для економії під час конспектування. Під час дослідження було визначено, що інтелект-карти є хорошим засобом для вивчення лексики, нового граматичного матеріалу, для перевірки рівня знань і повторення. Ментальні карти мотивують, полегшують процеси запам'ятовування та сприяють активності учнів на уроці.

Було 3'ясовано, що інтелектуальні карти допомагають розвитку критичного мислення, а це $\epsilon$ важливою передумовою розвитку підлітків. Перевагою методу є його універсальність для всіх школярів незалежно від індивідуальних особливостей пам'яті. 


\section{ЛITЕРАТУРА}

1. Бос Э. Как развивать креативность / пер. с нем. Петросян К.А. Ростов на Дону : Феникс, 2008. 189 с.

2. Бьюзен Т. Супермышление / пер. с англ. Самсонов Е.А. Минск : Попурри, 2006. 304 с.

3. Бьюзен Т., Бьюзен Б. Интеллект-карты. Практическое руководство / пер. с англ. Самсонов Е.А. Минск : Попурри, 2010. 352 с.

4. Ильин Е.П. Психология творчества, креативности, одаренности. Санкт-Петербург : Питер, 2009. 448 с.

5. Іноземна мова. Програми для загальноосвітніх навчальних закладів, 5-9 класи. URL: https://www.ippo.if.ua/predmety/inoz/ index.php?r=site/stattya\&id=191.

6. Інтелект-карта: мистецтво мислити ширше. URL: http://osvitanova.com.ua/posts/1232-intelekt-karta-mystetstvo-myslytyshyrshe.

7. Лейтес Н.С. Возрастная одаренность и индивидуальные различия. Москва : Институт практической психологии; Воронеж : МОДЭК, 1997. $448 \mathrm{c.}$

8. Любарт Т., Муширу К., Торджман С., Зенасни Ф. Психология креативности. Москва : Когито-Центр, 2009. 215 с.

9. Amabile T.M. Entrepreneurial creativity through motivational Synergy. Journal of Cretive Behavior. 1997. № 31 (1). P. 18-26.

10. Buzan T. The Mind Map Book. BBC Books : London, 1995.

11. Clayton M., Buzan T. Mind mapping. Management Pocketbooks. URL: https://www.pocketbook.co.uk/blog/2016/09/27/tony-buzan-mindmapping/.

12. Інтелект-карти - реальний крок у сучасній освіті. URL: http://shkola.ostriv.in.ua/publication/code-64C00512193D9.

13. Mindmap effektive Lernen Methode. URL: https://www.edrawsoft.com/de/mindmap-examples-for-students.php.

\section{Information about the author:} Pavlenko V. V.,

$\mathrm{PhD}$ in Pedagogic Sciences, Associate Professor, Associate Professor at the Department of Pedagogic Zhytomyr Ivan Franko State University 40, Velyka Berdychivska str., Zhytomyr, 10008, Ukraine 